\title{
Identifying Students' Error in Writing Islamic Text at the Third Semester of English Study Program at IAIN Bone
}

\author{
Abdul Rahman \\ Sekolah Tinggi Ilmu Administrasi (STIA) Prima Bone \\ bhinekatunggalika298@gmail.com
}

\begin{abstract}
This research aimed to find out the most common errors do the students made in their writing Islamic text at the third semester of English Study program IAIN Bone in Academic Years 2018-2019. The data were collected from the students' writing of the third semester. The key instrument used was writing test result and interview. This research used descriptive research. It refers to the descriptive qualitative. Qualitative data described each category that occurred in the students' writing. The researcher described the situation about the occurrence of the errors in the students' writing. The total number of lexical errors that the researcher found in the students' writing Islamic text was 150 errors that consisted of lexicon category was 68 errors and surface strategy was 82 errors. Most of the students' errors in the lexical category were sentence pattern. Sentence pattern is the highest errors made by the students in writing Islamic text with 10 students or $62.50 \%$ made errors; the second was punctuation and article by 5 students or $31.25 \%$; the third errors in spelling by 4 students or $25 \%$; the fourth errors in vocabulary and preposition by 3 students or $18.75 \%$; the last errors in tense, pronoun, and conjunction by 1 student or $6.25 \%$. It is figured out that the students have less ability in writing a text and still have difficulties in learning grammatical structures in writing process.
\end{abstract}

Keywords: writing ability, error analysis, Islamic text

\section{Introduction}

Writing is one of productive skills in language learning, the writing activity is different from other activities (Harmer, 1991). According to (Linse, 2006), writing is a combination of process and product of discovering ideas, putting them on paper and working with them until they are presented in manner that is polished and comprehensible to readers, it is less spontaneous but more permanent since it takes much time and concentrated practice. Writing is difficult to learn because authors should utilize a process that includes planning, organizing, and revising to present meaning in words form ( Palmer, 1994 in Alfiani 2012 ).

English language learning is a process where all skills of English (listening, reading, writing, speaking and grammar) are interconnected (Baker, 2011). As an example when someone wants to deliver his feeling or thought by writing, he has to notice not only the vocabulary but also the grammar. In writing, as one of the components of a language, grammar is necessary in order to create meaningful and understandable sentences In fact, they find English rules very complicated because some language features such as sentence construction, grammar, vocabulary, spelling and so forth in their mother tongue are different from those of the target language and these make them difficult to express themselves in a clear, correct and comprehensible manner of writing. 
According to (Harmer, 2015) says that writing has a number of conventions which separate it out from speaking and apart from differences in grammar and vocabulary, it means that writing offers opportunities to increase students' vocabulary, knowledge of grammar and develops their understanding of how things are expressed and how well students' message is understood in the written form.

Likewise, university students are often using the way of thinking and concept from their native language to express their ideas in English as well and they need to learn how to transfer their knowledge of rule/grammatical concepts of target language from oral language to written language. The researcher assumes that the difficulties in applying the rules of the language in writing cause students make errors. These problems are the reasons why students make errors in writing text.

Considering writing skills are important for teachers to be, the researcher tried to investigate possible linguistic problems by analyzing the errors writing of the third semester students of English study program at IAIN Bone. The researcher applied errors analysis on Lexicon category and surface strategy taxonomy due to this category related to students' writing skill on grammatical structure. Surface strategy taxonomy is a superficial of error classification used as a starting point for systematic analysis, thus the researcher used surface strategy taxonomy as a starting point in the description of errors and it involves four subcategories; they are omission, addition, misformation, and misordering errors. This is why the researcher interested in conducting this research.

\section{The Concept of Error Analysis}

An error analysis is the study and evaluation of uncertainty in measurement. It implies that error has a positive role in language learning since it is the sign that a language learner does not learn the rules of the target language effectively (Hendrawaty, 2018). Error analysis emphasizes the significance of errors in learners' interlanguage system and it is a type of linguistic analysis that focuses on the errors learners make (Brown, 1994). As the process to observe, analyze, and classify the deviations of the rules of the second language and then reveal the systems operated by learners (Brown, 1994). Another concept of error analysis stated by (Gass \& Selinker, 2008) that error analysis is a type of linguistic analysis that focuses on the errors learner make.

Language errors can be classified into two main parts: interlingual and intralingual errors. Interlingual errors can be detected as transfer errors caused by a learner's mother tongue merits such as lexical errors, grammatical errors, or pragmatic errors. Intralingual errors can be attributed to the ignorance of rule restrictions, imperfect implementation of rules, and false concepts assumed which all lead to overgeneralization (Richards \& Schmidt, 2002)

On the basis of definitions above, it can be assumed that error analysis is a process to observe, analyze, and classify the errors which are always made by learners either in speaking or writing. It also brings information about learners" difficulties in learning speaking or writing especially in English. The errors can help teacher, lecturer or researcher in teaching and learning process to observe the background why learners make the errors.

Error is a deviation that is consistently done by a language learner. This is because the learner's gap in knowledge. Dulay also classified Error into four items: 


\section{a. Linguistic Category}

In the first item, Errors are classified according to language component and the particular linguistic constituent the error affect or both. Language component include: a) phonology (pronunciation), b) syntax and morphology (grammar), c) semantic and lexicon (meaning and vocabulary), d) discourse (style).

\section{b. Surface Strategy}

The surface strategy focuses on the change of the structure in a written language. The student may add important thing or omitt unimportant thing in their writing; they also may misform items is classified into four types:

1) Omission is a kind of error that characterized by the absence of an item that must appear in well-formed utterance of target language. For example, "I was Cooking" becomes "I cooking".

2) Addition is a the opposite of the omission. This kind of error that characterized by the presence of an item that must not appear in a well-formed utterance of target language. For example, "I visited my grandma's house" becomes "I visited to my grandma's house".

3) Misformation is a kind of error that characterized by the use of the wrong form of the morpheme or structure. For example, "the bus came late" becomes "the bus comed late".

4) Misordering is a kind of error that characterized by the incorrect placement of a morpheme or group of morphemes in a utterance of target language. For example, "I wanted that red bag" becomes "I wanted that bag red".

c. Comparative Analysis

The classification of errors in a comparative taxonomy is based on comparisons between the structure of L2 errors and certain other types of constructions. Most of the second language learner's error have been compared to the error which made by the children who learn the target language as the first language. So, the errors made by the second language learners are compared to the error made by the native speaker of the target language.

\section{d. Communicative Effect}

The communicative effect deals with the perspective of the listener or reader toward the language produced by the foreign language learner. The listener or the reader understand the language produced by the foreign language learner or not becomes the focus in communicative effect.

\section{Method}

\section{Research Design}

This research belongs to descriptive research by using qualitative technique. This research belongs to descriptive because the objective of the research is to describe the phenomena from the data that are derived from observational situation. The researcher describes the phenomena of the obtained data naturally and objectively

\section{Location and Subject of the Research}

The location of this research took place at IAIN Bone at Jalan Hos Cokroaminoto, West Tanete Riattang Subdistrict, Bone District. The subject in this research focused on the third semester students of English Study Program IAIN Bone in Academic Year 2018-2019. 


\section{Instrument of the Research}

a. Writing Islamic Text

Writing test was used to know students errors in writing Islamic text. The researcher provided three topics about islamic text (Al-Fatihah, Fasting in Islam and Muhammad Is the last prophet of Islam). Then, students were asked to write some paragraphs according to the topics.

\section{b. Interview}

Interview is a method which permits an exchange of ideas information. The researcher used list of unstructured question to interview. With this, the researcher conducted an interview to the students to know the students' errors writing in Islamic text.

\section{Procedure to Collecting Data}

To collect of the data in this research used writing result test and interview. The first procedure was writing test. In this research, the students chose one of three topics and develop the topic into some paragraphs. Then, the researcher identified the students' common errors in writing. The second prosedure was interview. In the interview, the researcher asked some questions to the students related to their difficult in writing islamic text. It recorded and transcribed.

\section{Technique of Data Analysis}

The data of this research were analyzed by using several steps. Firstly, the researcher collected the students' writing test to be analyzed according to Dulay's theory. They were studied carefully. Secondly, the errors were classified into four subcategories of surface strategy taxonomy by selecting and identifying the errors that belong to grammatical structure in students' writing. The errors found in clauses and sentences. A sentence may contain one error or more, and then they were analyzed separately. Thirdly, the data were interpreted and described systematically according to the types of error. The errors were identified and classified into the subcategories of comparative taxonomy. The last step was errors evaluation by tabulating the errors to get the percentage of each subcategory. In this step, the frequencies of errors were identified and the numbers of errors were presented in the forms of tables. The formula of the percentage was presented as follows (Dulay, Burt, \& Krashen, 1982)

$$
\% \text { Type of errors }=\frac{\sum \text { Student's errors on each category }}{\sum \text { Student's errors }} \times 100 \%
$$

Not only used the percentage by Dulay's theory but the researcher also used percentage by Nasution to see the percentage of students' correct answer and wrong answer in errors writing Islamic text. which the formula as follows (Nasution, 1995) :

$P=\frac{\mathrm{F}}{\mathrm{N}} \times 100 \%$

$\mathrm{P}=$ Percentage

$\mathrm{F}=$ Frequency of error occurred

$\mathrm{N}=$ Number of cases (total frequent / total individual) 
Interview will be processed with some stages are as follows:

a. Data reduction

Data reduction was a form of analysis that sharpens, classifies, directs, discards the unnecessary and organize the data in such a way that the final conclusion can be drawn.

\section{b. Presentation of data}

Presentation of data was an actifity when a set of information is prepared, thus giving the possibility of conclusion. Form of the presentation in the form of Islamic text.

c. Withdrawal conclusion

A conclusion was the result of an analysis that can be used to take action. In this section, the researcher will express the conclusions of the data that have been obtained. This activity is intended to find the meaning of data collected by looking for writing error in Islamic text.

\section{Results}

To know the description of the students' errors in writing, the writer identified and classified errors into 2 aspects: Lexicon category and surface strategy. Then the writer made the reconstruction of the errors' writing which made by the students.

\section{The Types of Students' Error in Writing Islamic Text}

This research was analyzed based on (Dulay et al., 1982) theory, the surface strategy taxonomy which concerns on omission, addition, misordering error. These errors defined as mechanics (spelling and punctuation), grammar, and word choices. To find out the types of errors, the researcher documented the students' writing. After that, the percentage of each category of errors in their writing was counted.

Table 1. The Tabulation of Students' Error in Writing

\begin{tabular}{|c|c|c|c|}
\hline No. & Error Classifications & Frequency & Percentage (\%) \\
\hline \multirow[t]{10}{*}{1} & Lexicon Category: & & \\
\hline & a. Sentence Pattern & 20 & $29.41 \%$ \\
\hline & b. Tenses & 3 & $4.41 \%$ \\
\hline & c. Pronoun & 1 & $1.47 \%$ \\
\hline & d. Spelling & 25 & $36.76 \%$ \\
\hline & e. Vocabulary & 3 & $4.41 \%$ \\
\hline & f. Punctuation & 7 & $10.29 \%$ \\
\hline & g. Article & 5 & $7.35 \%$ \\
\hline & h. Conjunction & 1 & $1.47 \%$ \\
\hline & i. Preposition & 3 & $4.41 \%$ \\
\hline Total & & 68 & $100 \%$ \\
\hline \multirow[t]{4}{*}{2} & Surface Strategy & & \\
\hline & a. Omission & 54 & $65.85 \%$ \\
\hline & b. Addition & 25 & $30.48 \%$ \\
\hline & C. Misordering & 3 & $3.65 \%$ \\
\hline Total & & 82 & $100 \%$ \\
\hline
\end{tabular}

The table above shows that the students' error in writing Islamic text on lexicon category namely; $29.41 \%$ of sentences pattern errors, $4.41 \%$ errors in tenses, $1.47 \%$ error in pronoun, $37 \%$ errors in spelling, $4.41 \%$ errors in vocabulary, $10.29 \%$ errors in punctuation, $7.35 \%$ errors in article, $1.47 \%$ error in conjunction, and $4.41 \%$ errors were found in preposition. While in the 
surface strategy there were $65.85 \%$ errors in omission, $30.48 \%$ errors in addition, and $3.65 \%$ errors in misordering.

To make the data clear, here was the table the percentage of the students' right and wrong answer in writing Islamic text:

Table 2. The Percentage of the students' answer in writing Islamic text in Lexicon Category:

\begin{tabular}{lrrrr}
\hline Classification Errors & $\begin{array}{r}\text { Frequency of } \\
\text { wrong answer }\end{array}$ & $\%$ & $\begin{array}{r}\text { Frequency of } \\
\text { right answer }\end{array}$ & $\%$ \\
\hline Sentence Pattern & 10 & $62.50 \%$ & 6 & $37.50 \%$ \\
Tenses & 1 & $6.25 \%$ & 15 & $93.75 \%$ \\
Pronoun & 1 & $6.25 \%$ & 15 & $93.75 \%$ \\
Spelling & 4 & $25 \%$ & 14 & $75 \%$ \\
Vocabulary & 3 & $18.75 \%$ & 13 & $81.25 \%$ \\
Punctuation & 5 & $31.25 \%$ & 11 & $68.75 \%$ \\
Article & 5 & $31.25 \%$ & 11 & $68.75 \%$ \\
Conjunction & 1 & $6.25 \%$ & 15 & $93.75 \%$ \\
Preposition & 3 & $18.75 \%$ & 13 & $81.25 \%$ \\
\hline
\end{tabular}

Based on the table above, the researcher states that the highest errors are made by students in writing Islamic text is sentence pattern errors there are 10 students or $62,50 \%$ made errors, the second is punctuation and article by 5 students or $31.25 \%$, the third errors in spelling by 4 students or $25 \%$, the fourth is errors in vocabulary and preposition by 3 students or $18.75 \%$ an the last is errors in tense, pronoun, and conjunction by 1 students or $6.25 \%$. These errors described the problem which students face in their writing and the students also are still need to improve their ability to write a text because they tend to make errors in writing as the result of their native language transfer since they have not been familiar with the English language system which makes them lack of competence to the target language.

\section{Discussion}

In preceding explanation, the data were taken from students' errors in writing Islamic text. The writer classified the students' errors in writing. Then the writer only focused on two areas: Lexicon Category (Sentence Pattern, Tenses, Pronoun, Preposition, Punctuation, Article, Conjunction and Spelling) and Surface Strategy (Omission, Addition, and Misordering). Here were the explanations about the calculation and interpretation of the data:

\section{Lexicon Category}

From the data of the students, the researcher found many errors in lexicon category form that made by the students. Many lexical items consist of more than one word, and have a structure of their own. So, lexical errors are learners' error in word and which is ungrammatical. Here are the explanation about calculation and interpretation of the data:

\section{Sentence Pattern}

Among 16 students who became the sample, $29.41 \%$ total of errors made by the students in sentence pattern. The writer assumed that this error caused by the Mother Tongue Interference or error resulting from the transfer of grammatical and stylistic elements from the source language to the target language. We can classify the errors in Sentence Pattern as the errors in Omission because the students sometimes forget to put the subject or the verb whereas it is very important in making a sentence. 
Tense

Tense error was committed by the third semester students of IAIN Bone. Among 16 students who became the sample, $4.41 \%$ total of errors made by the students in Tense. The writer assumed that tense was not a problem for students when they wrote Islamic text. Because of from 16 students only 1 student makes error in this item. The errors in Tense also happened because of Translation means a student translates his first language sentence or idiomatic expression in to the target language word by word. We can classify the errors in sentence pattern as the errors in Omission. Certain linguistic forms may be omitted by the learners because of their complexity in production. Omission also occurs in morphology for example the past tense inflection -ed.

\section{Pronoun}

There was 1 or (1.47\%) student made errors in pronoun with the percentage $93.75 \%$ or 15 students were true in using Pronoun in their writing. A pronoun is a word that is used in the place of a noun or noun phrase. Pronoun errors happened because of Overgeneralization that is an error caused by extension of target language rules to areas where they do not apply. We can classify the errors in Pronoun as the errors in Selection because the students still confuse to choose and to use the word to be the right pronoun.

\section{Spelling}

$75 \%$ or 12 students made errors in Spelling. The errors in spelling occurred because of the Carelessness when the students wrote because most of the students did not know aware about the spelling of the word. We can classify the errors in Spelling as the errors in Selection because the students made errors in writing the word to be the right spelling.

\section{Vocabulary}

$18.75 \%$ or 3 students made errors in vocabulary in writing Islamic text. The errors in vocabulary occurred because the students are not being able to choose the right vocabulary in writing. We can classify the error in vocabulary as the errors in syntax and semantic aspect.

\section{Punctuation}

$31.25 \%$ or 5 students made errors in Punctuation. The errors in Punctuation occurred because of the Carelessness when the students wrote because most of the students did not know aware about the Punctuation. They sometimes forget to put punctuation mark the end of the sentence that they wrote. We can classify the errors in Punctuation as the errors in Selection because the students made errors in writing the word to be the right Punctuation.

\section{Article}

$31.25 \%$ or 5 students made errors in writing an article. The errors in article occurred because of the Carelessness when the students wrote because most of the students did not know aware about how to write the right article. In this research the writer found some errors were made by students in writing article like, a obligation and the right words is an obligation. They sometimes confuse to put the right article in front of a word in the sentence that they wrote. We can classify the errors in article as the errors in syntax and semantic aspect.

\section{Preposition}

3 students made errors in Preposition with the percentage $6.25 \%$ in Preposition when they were writing Islamic text. Preposition errors also happened because of Overgeneralization that 
is an error caused by extension of target language rules to areas where they do not apply. Prepositions are usually quite short and significant looking, but they have very important functions to link a noun to another word. We can classify the errors in Preposition as the errors in Omission because the students commonly omit the preposition' words such as at, of, in, for, by, etc.

Below are some results of the students' interview about errors in writing Islamic text:

\section{Student 1:}

$\mathrm{R}$ : According to you, what is writing? Could you explain?

S1: Writing is a media is used by someone to communicate or make a note.

$\mathrm{R}$ : What is Error?

S1: An Error that cannot be corrected again.

$\mathrm{R}$ : What are difficulties you face when writing a text in English about Islamic text?

S1: One of my difficulties in writing is I sometimes confuse to choose a word that are suitable to be used in a sentence and not only that the choice of conjunctions also is very difficult for me.

\section{Students 2:}

$\mathrm{R}$ : According to you, what is writing? Could you explain?

S2: Writing is a medium of human communication that represents language with symbols

$\mathrm{R}$ : What is Error?

S2: Errors are the flawed side of learner speech or writing. It means that learners cannot learn language without systematically committing errors first.

$\mathrm{R}$ : What are difficulties you face when writing a text in English about Islamic text?

S2: One of my difficulties in writing is I cannot express my idea in English caused by lack of vocabulary and inability to write with the right grammar. I also have problem using schematic structure according to the selected essay.

According to the result of interviews above, the researcher concludes that the students often make errors in writing a text, it is proved by the result of the interviews with student 1 says that one of her difficulties in writing is sometimes confuse to choose words that are suitable to be used in a sentence and not only that the choice of conjunctions according to her is very difficult.

The next student said that writing is a medium of human communication that represent language with symbols, she also face some difficulties in writing Islamic text like, she cannot express her idea in English caused by lack of vocabulary and inability to write with the right grammar. She also has problem using schematic structure according to the selected essay.

Based on the result of the interview above, the writer connects with the statement from (Vendityaningtyas \& Styati, n.d.) in Byrne states that he categorizes three problems that made writing skill difficult to master, namely; linguistic, cognitive, and content problems.

The first problem is Linguistic. This is related to our shrewdness in writing down the structure the right and therefore the sentences that are formed will be able to blend together. The second problem is cognitive problem related to mastery we are in the form of language, structure, grammar that is useful for communication effective in writing. And the third is a problem about ideas. This is related to anything that can we put it in writing. We often lose ideas in the middle of the writing process.

Making errors is an important aspect to get information whether it is caused by grammatical error or slip of the tongue either in spoken or written language. It is connected with interview of the researcher with one of the students says that: 
Student 3:

$\mathrm{R}$ : Why are errors in writing a text so important to know?

S3 : Because everyone has made a lot of error when they are writing, so it is very important to know the errors we made, so that we can improve our writing ability.

According to students in the result of the interview above, the researcher concludes that errors should be analyzed because they give a contribution in understanding the process of language learning. From their errors, learners can get feedback which can be used to find new attempts to achieve the goal of learning. It contains information on strategies that learners use to acquire language and can play an important role in the study of foreign language.

\section{Surface Strategy}

The surface strategy focuses on the change of the structure in a written language. The student may add important thing or omitt unimportant thing in their writing; they also may misform items.

Omission is a kind of error that characterized by the absence of an item that must appear in well-formed utterance of target language. In this research, the writer found many errors were made by students in omission. There were 54 total errors in omission from 16 students or $65.85 \%$. It occurred because they were not careful write a word in writing a sentence, so there were some words that they didn't put in the sentences. For example, "Prophet was Muhammad born in approximately 570 year of the Elephant" becomes "Prophet Muhammad born in approximately 570 year of the Elephant".

Addition is a the opposite of the omission. This kind of error that characterized by the presence of an item that must not appear in a well-formed utterance of target language. In this research, the writer found many errors were made by students in addition. There were 25 total errors in addition from 16 students or $30.48 \%$. For example, "Al-Fatihah is required to read when they pray" becomes "Al-Fatihah is required to reading when they pray".

Misordering is a kind of error that characterized by the incorrect placement of a morpheme or group of morphemes in a utterance of target language. In this research, the writer found some errors were made by students in misordering. There were 3 total errors in addition from 16 students or $3.65 \%$. It means that only a few students did an error in misordering. For example, "Al-Fatihah has become the breath for Islam people in Northern of the word" becomes "Al-Fatihah has become the breath for people Islam in Northern of the word".

\section{Conclusion}

The data of this study took from English composition written by the third semester student of English department at IAIN Bone I Academic Year 2018-2019. The findings in this study show that there were many lexical errors found in the students' writing text. It can be looked from the lexical errors that appear in their compositions. Although the students know well the words they are using and difficult English spelling make them confused to write the lexical items.

Data from the present research points to the fact that the total number of lexical errors that the researcher found in the students' writing Islamic text was 150 errors that consisted of lexicon category was 68 errors and surface strategy was 82 errors. And the findings of this research also found that most of the students' errors in the lexical category are sentence pattern. Sentence pattern is the highest errors made by the students in writing Islamic text with 10 students or $62.50 \%$ made errors; The second is punctuation and article by 5 students 
or $31.25 \%$; The third errors in spelling by 4 students or $25 \%$; The fourth is errors in vocabulary and preposition by 3 students or $18.75 \%$; The last is errors in tense, pronoun, and conjunction by 1 student or $6.25 \%$.

Based on these findings, the researcher concludes that the Third Semester of English Study Program IAIN Bone in Academic Year 2018-2019 have less ability in writing a text. Most of students' errors are dominated by sentence pattern and omission. Therefore, these errors describe the problems which students face in writing Islamic text.

\section{References}

Baker, C. (2011). Foundations of Bilingual Education and Bilingualism. Multilingual Matters. Brown, H. D. (1994). Principles of Language Learning and Teaching. Prentice Hall Regents. Dulay, H. C., Burt, M. K., \& Krashen, S. D. (1982). Language two. Oxford University Press. Gass, S. M., \& Selinker, L. (2008). Second Language Acquisition: An Introductory Course. Routledge.

Harmer, J. (1991). The Practice of English Language Teaching. Longman.

Harmer, J. (2015). The Practice of English Language Teaching. Pearson Education.

Hendrawaty, N. (2018). An Analysis On Students' Errors In Writing Sentence Patterns, 11(01), 23.

Linse, C. T. (2006). Practical English Language Teaching: Young Learners. McGraw-Hill.

Nasution, S. (1995). Metode research (penelitian ilmiah): usul tesis, desain penelitian, hipotesis, validitas, sampling, populasi, observasi, wawancara, angket. Bumi Aksara.

Palmer, B. C. (1994). Developing Cultural Literacy Through the Writing Process: Empowering All Learners. Allyn and Bacon.

Richards, J. C., \& Schmidt, R. W. (2002). Longman Dictionary of Language Teaching and Applied Linguistics. Longman.

Vendityaningtyas, V., \& Styati, E. W. (n.d.). Prosiding Seminar Nasional Hasil Penelitian, 6. 